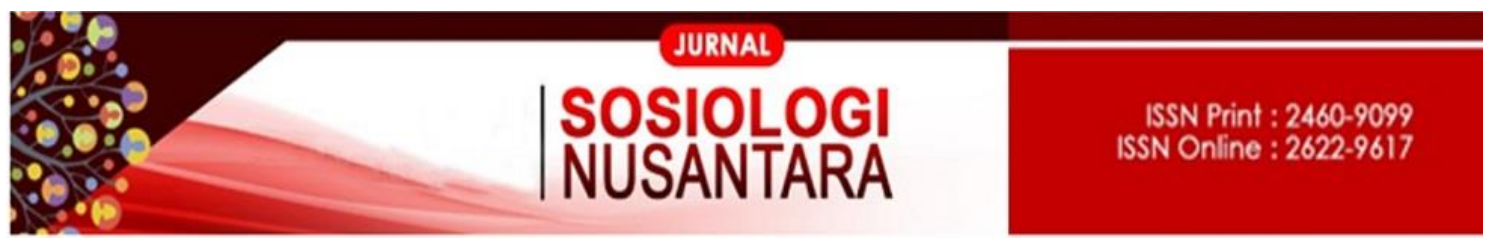

https://ejournal.unib.ac.id/index.php/jsn

DOI ://doi.org/10.33369/jsn.4.2.85-97

\title{
STRATEGI BERTAHAN HIDUP PENGEMIS TUNANETRA (Studi Pada Pengemis di Lampu Merah Sukamerindu)
}

\author{
The Survive Strategy of the Blind Beggar \\ (Study in Sukamerindu Red Light) \\ Zukna $^{1}$, Hasan Pribadi², Heni Nopianti ${ }^{3}$ \\ zuknaakhira88@gmail.com \\ 123. Fakultas Ilmu Sosial dan Ilmu Politik, Universitas Bengkulu
}

\begin{abstract}
Abstrak
Penelitian ini bertujuan mendeskripsikan strategi yang dapat dilakukan oleh pengemis tunanetra untuk memenuhi kebutuhan hidupnya, dilokasi Lampu Merah Sukamerindu Kota Bengkulu. Metode yang digunakan yaitu kualitatif dengan teknik observasi, wawancara, dokumentasi, teknik triangulasi (keabsahan data) dan teknik snowball sampling untuk mendapatkan data yang lebih objektif. Teori yang digunakan berupa teori aksi karya Max Weber yang termasuk dalam paradigma definisi sosial. Penelitian ini menghasilkan informasi tentang strategi yang dilakukan pengemis tunanetra dalam bertahan hidup dan bertahan menjadi pengemis. Strategiyang dilakukan oleh pengemis tunanetra yaitu: strategi aktif dengan pengoptimalan anggota keluarga dalam mencari uang, strategi pasif dengan penghematan dalam memenuhi kebutuhan pokok dan strategi jaringan dengan kelompok Pertuni yang memberikan dampak positif untuk mengatasi himpitan ekonomi yaitu membentuk kelompok arisan dan saling meminjamkan uang. Sedangkan strategi dalam mengemis meliputi pemilihan waktu dan lokasi mengemis.
\end{abstract}

Kata Kunci: Pengemis Tunanetra dan Strategi Bertahan Hidup.

\begin{abstract}
This study aims to describe strategies can be done by blind beggars to meet the needs of his life, at the location of Sukamerindu Red Light Bengkulu City. The method used is qualitative with observation technique, interview, documentation, triangulation technique (data validity) and snowball sampling technique to get more objective data. The theory used Max Weber's action theory which is included in the social definition paradigm. This research produces information about the strategies that blind beggars do in survival and persists into beggars. Strategies undertaken by blind beggars are: active strategy in the form optimization family members in the search for money, passive strategy in the form saving in the fill main necessary and network strategy in the
\end{abstract}


86 | Zukna, Hasan Pribadi, Heni Nopianti

Strategi Bertahan Hidup Pengemis Tunanetra

form Pertuni group extend positive impact for resolve economy. While the strategy in begging include the selection of time and location begging.

Keywords: Blind beggar and Surviving Strategies

\section{PENDAHULUAN}

Indonesia merupakan negara berkembang yang memiliki jumlah penduduk yang tinggi dan perekonomian yang masih lemah. Setiap tahunnya jumlah penduduk Indonesia terus mengalami peningkatan bahkan pada tahun 2010 jumlah penduduk Indonesia mencapai 237,6 juta jiwa (BPS, 2010). Permasalahan antara ekonomi dan ledakan penduduk menjadi hal yang wajar yang menyebabkan kemiskinan di perkotaan maupun di pedesaan.

Bengkulu merupakan salah satu provinsi yang mempunyai masalah terhadap rendahnya kesejahteraan pada masyarakat kota. Menurut Pramudyasmono (2011: 152) salah satu upaya yang dapat dilakukan untuk meningkatkan standar kehidupan masyarakat miskin di Kota Bengkulu adalah melalui pemberdayaan.

Salah satu penyebab maraknya jumlah pengemis di Kota Bengkulu adalah tingginya tingkat kemiskinan pada masyarakat. Kajian mengenai pengemis tunanetra perlu untuk diteliti karena fenomena yang terjadi antara kemauan pengemis untuk meminta-minta dan pandangan masyarakat yang berlawanan (mengemis atau memintaminta merupakan malas untuk bekerja) serta strategi kehidupan yang dapat mereka lakukan untuk bertahan hidup. Selain itu uniknya pengemis tunanetra dalam mengemis selalu didampingi, berbeda halnya dengan pengemis cacat lainnya.

Fokus masalah dalam penelitian ini adalah cara atau strategi bertahan hidup pengemis tunanetra dalam memenuhi kebutuhan hidup sehari-hari.Tujuan dari penelitian ini adalah untuk mengetahui strategi yang dapat dilakukan oleh pengemis tunanetra untuk memenuhi kebutuhan hidup serta bertahan hidup dari hasil belas kasihan masyarakat dan juga untuk mengetahui faktor dari dipilihnya strategi tersebut. Teori yang digunakan adalah teori aksi dengan paradigma definisi sosial.

\section{METODE PENELITIAN}

Penelitian ini menggunakan metode penelitian deskriptif kualitatif dan dilakukan di lingkungan Lampu Merah Sukamerindu Kota Bengkulu yang merupakan salah satu tempat strategis pengemis untuk meminta-minta. Metode pengumpulan data 
yang digunakan dalam penelitian ini yakni dengan menggunakan metode observasi, wawancara, dan dokumentasi. Penentuan informan dalam penelitian ini dilakukan dengan menggunakan teknik snowball sampling. Informan yang dipilih oleh peneliti dalam penelitian tentang strategi bertahan hidup pengemis tunanetra ini dikelompokkan menjadi dua yaitu:

a. Informan Kunci (Pelaku)

Informan kunci dalam penelitian ini berjumlah 8 orang. Informan kunci dalam penelitian ini ada 6 orang, yaitu pengemis tunanetra dan keluarga (Bgs, Sry, Mw, Az, Ad, Dn). Pemilihan informan kunci oleh peneliti berdasarkan kriteria sebagai berikut:

1) Informan kunci yang dipilih adalah pengemis tunanetra yang memiliki keluarga.

2) Pengemis tunanetra yang sudah lama mengemis (3 tahun ke atas).

3) Keluarga pengemis tunanetra yang hidup bersama (tinggal serumah dengan pengemis tunanetra).

b. Informan Tambahan

Informan tambahan dalam penelitian ini berjumlah 2 orang yang merupakan pendamping pengemis tunanetra dan tetangga atau masyarakat ( $\mathrm{Bb}$ dan $\mathrm{Sw}$ ) yang tinggal disekitar tempat tinggal pengemis tunanetra. Teknik analisis data menggunakan teknik keabsahan data dengan teknik triangulasi dengan menggunakan 3 teknik analisis yang digunakan yakni reduksi data, penyajian data, serta penarikan kesimpulan.

\section{PEMBAHASAN}

\section{Persiapan Mengemis}

Persiapan yang harus disiapkan adalah memakai pakaian yang lusuh atau pakaian yang sudah tidak bagus lagi untuk menarik belas kasihan orang-orang, selanjutnya pengemis tunanetra menunggu jemputan dari pendamping pengemis tunanetra (biasanya diantar jemput di rumah pengemis tunanetra), pengemis tunanetra mulai beroperasi dari jam 9.00 WIB sampai jam 17.30 WIB (dilakukan dihari-hari biasayang dianggap aman oleh para pengemis tunanetra dari razia Satpol PP). Sedangkan dibulan Ramadhan biasanya Satpol PP sering mengadakan razia penangkapan gepeng (gelandangan dan pengemis) yang ada dijalanan. Jam beroperasinya para mengemis tunanetra untuk mengemis dimulai dari jam 5 pagi di pasar-pasar tradisional seperti Pasar Minggu dan Pasar Panorama sedangkan di siang 
88 | Zukna, Hasan Pribadi, Heni Nopianti

Strategi Bertahan Hidup Pengemis Tunanetra

harinya jam 2 sampai sore mengemis keliling dan mengemis di PTM (pasar tradisional modern).

\section{Penghasilan Pengemis Tunanetra}

Pendapatan sehari-hari para pengemis tunanetra beragam atau tidak menentu. Berdasarkan wawancara dilapangan penghasilan yang didapatkan pengemis tunanetra perharinya berkisar dari Rp.40.000,00 sampai Rp.70.000,00. Pendapatan para pengemis tunanetra tidak tetap disetiap harinya. Setelah uang terkumpul di sore hari, pendapatan para pengemis tunanetra pun dibagi dua dengan pendamping yang menuntun mereka mengemis.

\section{Strategi Bertahan Hidup Pengemis Tunanetra Di Kota Bengkulu}

\section{Strategi Aktif (Optimalisasi Potensi Keluarga)}

Salah satu cara untuk meningkatkan penghasilan yang dapat dilakukan olehkeluarga pengemis tunanetra yaitu dengan memanfaatkan seluruh potensi anggota keluarga demi mendapatkan uang. Selain suami, anak dan istri keluarga pengemis tunanetra harus membantu menghasilkan uang untuk memenuhikebutuhan pokok keluarga.

\section{A. Peran Suami}

Meskipun memiliki kekurangan yaitu cacat pada matanya seorang tunanetra yang menjadi salah satu informan dalam penelitian ini yang berinisial Bgs tetap menjalankan tanggung jawabnya baik sebagai ayah maupun sebagai seorang suami bagi istrinya serta sebagai sumber pencari nafkah utama dalam keluarganya. Bapak Bgs berprofesi sebagai pengemis tunanetra yang berusia 55 tahun, yang tinggal di rumahnya yang berlokasi di Rawa Makmur. Bapak Bgs sudah lama menjadi pengemis di jalanan, hampir 15 tahun lebih lamanya. Strategi aktif yang bersifat internal berupa berbagai usaha yang dapat dilakukan oleh bapak Bgs dalam menghidupi keluarganya, salah satunya bapak Bgs menyediakan jasa menjadi tukang urut tradisional.

Selanjutnya bapak Dn yang juga seorang kepala keluarga yang harus menghidupi anak istrinya. Bapak Dn mengemis setiap hari bersama istrinya ibu Az. Lain lagi dengan ibu Mw yang menjadi tulang punggung keluarga menghidupi ketiga 
anaknya yang masih kecil yang belum dapat membantu menghasilkan uang. Ibu Mw berperan ganda sebagai ibu sekaligus ayah bagi ketiga anaknya setelah ditinggalkan suaminya meninggal dunia. Hanya dengan mengemis saja ibu Mw menghidupi anaknya dan membuka usaha pijat tradisional untuk menambah pendapatan. Selanjutnya bapak Ad yang hidup sebatang kara yang mengemis dijalanan dan pasar-pasar. Bapak Ad hanya perlu memenuhi kebutuhan hidupnya saja, karena anak-anaknya sudah menikah dan bukan tanggungan bapak Ad lagi.

Selain dari penghasilan mengemis juga ada bantuan (strategi yang bersifat eksternal) dari pemerintah untuk keluarga miskin seperti keluarga pengemis tunanetra yaitu PKH (program keluarga sejahtera) dengan jumlah dana yang dicairkan Rp.450.000,00 setiap tiga bulan sekali cair. Informan peneliti (pengemis tunanetra) yang mendapat dana dari pemerintah untuk program keluarga harapan yaitu bapak Bgs dan ibu Sry, bapak Dn dan ibu Az serta ibu Mw.

\section{B. Peran Istri}

Ibu Az setiap harinya mendampingi suami mengemis dijalanan. Suami ibu Az adalah bapak Dn yang menjadi pengemis tunanetra. Selain menjadi pengemis ibu Az juga sempat menjadi pemulung untuk menambah pendapatan keluarganya. Selanjutnya ibu Sry juga seorang istri pengemis tunanetra (bapak Bgs) yang juga berprofesi sebagai pengemis tunanetra untuk menambah pemasukan atau penghasilan keluarganya. Selain menjadi pengemis ibu Sry juga membuat telur asin yang dijual di daerah kampung Klawi. Namun sekarang ibu seri lebih sering mengemis dari pada jualan telur asin. Alasannya berhenti berjualan karena ruangan rumahnya terlalu kecil untuk mengelola telur asin dan lebih memilih menjadi pengemis serta kadang-kadang bu Sry juga mengamen untuk mendapat tambahan lebih.

Lain lagi dengan ibu Mw yang menjadi tulang punggung keluarganya setelah ditinggalkan suaminya meninggal. Menghidupi anak-anaknya yang masih kecil hanya dengan hasil mengemis dan menjadi tukang urut serta mendapat bantuan dari pemerintah seperti bantuan PKH dan bantuan dari saudara-saudara suaminya.Sedangkan bapak Ad sudah tidak memiliki istrinya lagi. Istri bapak Ad meninggal dunia 15 tahunyang lalu di daerah Lebong. Bapak Ad mengemis dibantu oleh pendamping pengemis yang dibayarnya. 
90 | Zukna, Hasan Pribadi, Heni Nopianti

Strategi Bertahan Hidup Pengemis Tunanetra

\section{Peran Anak}

Dengan kondisi yang tidak normal tentunya hasil pendapatan yang didapatkan orang tua penyandang cacat tunanetra tidak akan maksimal seperti orang normal lainnya, ditambah lagi profesi yang dilakukan orang tuanya adalah seorang pengemis tunanetra yang memiliki pendapatan yang tidak menetap dan tidak menjanjikan. Hasil yang didapatkan bisa banyak dan juga bisa sedikit tergantung yang memberikan disetiap harinya. Salah satu anak ibu Az dan bapak Dn yang berumur 25 tahun yang juga membantu dalam mencari uang dengan berprofesi sebagai buruh bangunan. Selain anak ibu $\mathrm{Az}$, anak-anak dari keluarga pengemis yang menjadi informan lainnya rata-rata masih menjadi tanggungan oleh pengemis tunanetra karena anak-anaknya masih kecil dan belum bisa menghasilkan uang sendiri seperti anak pasangan suami istri bapak Bgs dan ibu Sry yang masih berumur 5 tahun dan 11 tahun dan anak ibu Mw yang berumur 1 tahun, anak keduanya berumur 7 tahun dan anak pertamanya berumur 11 tahun.

\section{Strategi Pasif (Meminimalisir Biaya Pengeluaran Keluarga)}

Harga kebutuhan sehari-hari semakin lama semakin mahal. Sedangkan penghasilan yang didapat oleh keluarga pengemis tunanetra tidak tetap. Hal semacam ini dapat menyulitkan keluarga pengemis tunanetra karena ketidakseimbangan antara pendapatan dengan pengeluaran yang dilakukan oleh keluarga pengemis tunanetra. Alternatif solusi yang dipilih yaitu dengan meminimalisir atau mengurangi biaya pengeluaran keluarga untuk kebutuhan sandang, pangan, papan, pendidikan dan kesehatan adalah sebagai berikut:

1. Biaya Kebutuhan Sandang

Pengamatan peneliti terhadap pakaian yang dipilih dan digunakan oleh pengemis tunanetra sangat sederhana dan apa adanya. Seperti baju seragam sekolah anak ibu Sry dan bapak Bgs (informan kunci peneliti) yang dibeli dengan harga murah (Rp.150.000,00) dan baju seragam anaknya ada juga yang diberikan oleh tetangganya. Sedangkan informan lainnya seperti bapak Dn, ibu Az, bapak Ad dan ibu Mw untuk memenuhi kebutuhan pakaian atau baju, hanya memakai baju hasil pemberian dari tetangga atau masyarakat dan sering juga dibantu oleh mahasiswa yang mendapatkan donasi dari masyarakat (mahasiswa yang sering memberikan bantuan berupa baju dan 
sembako adalah mahasiswa IAIN Bengkulu, menurut para informan peneliti). Membeli baju baru hanya diwaktu-waktu tertentu seperti saat hari raya itupun jika ada uang lebih.

Menurut ibu Mw kadang membeli baju baru dapat dilakukan dua tahun sekali. Pakaian para pengemis tunanetra saat mengemis dan pakaian sehari-harinya pun tidak jauh berbeda (diketahui peneliti saat pengamatan dilokasi mengemis dan di rumah pengemis tunanetra seperti ibu Sry dan bapak Bgs). Bagi pengemis tunanetra mutu atau kualitas pakaian tidaklah penting, bagi pengemis tunanetra yang penting adalah memiliki pakaian dan membeli baju barupun diwaktu-waktu tertentu. Baju yang lusuh dan celana yang biasa-biasa saja itulah pakaian yang sering para tunanetra gunakan sehari-harinya.

\section{Biaya Kebutuhan Pangan}

Untuk menghemat pengeluaran biaya pangan keluarga pengemis tunanetra, seperti yang dilakukan oleh ibu Az, sayuran-sayuran seperti kangkung dan genjer tidak dibeli di pasar melainkan dicari dirawa-rawa atau minta di sawah milik tetangga (strategi yang bersifat internal). Untuk kebutuhan pangan para pengemis tunanetra seperti ibu Mw juga dapat bantuan dari tetangga dan kerabat serta pemerintah (strategi yang bersifat eksternal). Untuk orang-orang yang tidak mampu atau berekonomi lemah pemerintah memberikan bantuan berupa uang yang dapat diterima dalam tiga bulan sekali cair sebesar Rp.450.000,00 yaitu bantuan pemerintah dalam program keluarga harapan $(\mathrm{PKH})$, selain itu juga adanya bantuan beras raskin yang diberikan pihak pemerintah kepada masyarakat miskin atau tidak mampu. Serta BPNT (bantuan pangan non tunai) yang diberikan pemerintah untuk membantu pemenuhan kebutuhan pangan masyarakat miskin seperti pengemis tunanetra.Bantuan Pemerintah BPNT ini berupa sejumlah beras dan telur yang diterima setiap bulan. Biasanya beras yang diterima sebanyak empat cupak dan telur satu karpet. Informan peneliti (pengemis tunanetra) yang mendapat dana dari pemerintah untuk program keluarga harapan dan bantuan pangan non tunai yaitu bapak Bgs dan ibu Sry, bapak Dn dan ibu Az serta ibu Mw.

\section{Biaya Kebutuhan Papan}

Rumah yang ditinggali oleh informan penelitian (pengemis tunanetra) ada yang milik pribadi ada juga yang masih menyewa. Informan yang sudah memiliki rumah 
sendiri seperti ibu Sry dan bapak Bgs, ibu Az dan bapak Dn sedangkan bapak Ad dan ibu Mw masih tinggal dirumah kontrakan.Rumah ibu Sry dan bapak Bgs dibangun pada tahun 2009 dan mulai ditempati pada akhir tahun 2009. Rumah milik ibu Sry dan bapak Bgs dengan ukuran 4x4 meter yang memiliki satu ruang kamar, ruang tamu, ruang dapur serta kamar mandi dan toilet. Informan selanjutnya bapak Dn dan ibu Az juga mempunyai tempat tinggal atau rumah sendiri. Bapak Dn dan ibu Az tinggal bersama anak bungsunya yang belum menikah, sedangkan anak-anaknya yang sudah menikah tinggal di Padang Sumatera Barat.

Sedangkan ibu Mw (40 tahun) tinggal di kontrakan dengan anak ketiganya yang masih kecil, ibu Mw menjadi tulang punggung keluarga karena suaminya meninggal sedangkan anak pertama dan anak keduanya dititipkan dipanti asuhan. Bayaran sewa rumah yang harus dibayar oleh ibu Mw sebesar Rp.2.300.000,00 pertahunnya. Bayaran sewa rumah milik ibu Mw sering dibantu oleh saudara-saudara almarhum suami ibu Mw. Selain ibu Mw bapak Ad (60 tahun) juga mengontrak sepetak gubuk yang dibayarnya setiap bulan sejumlah Rp.100.000,00. Kondisi rumah pengemis tunanetra yang ditempati seperti rumah milik pasangan suami istri ibu Sry dan bapak Bgs tidak begitu layak untuk ditinggali karena kondisi rumah yang kotor.

\section{Biaya Kebutuhan Pendidikan}

Untuk memenuhi kebutuhan pendidikan pada keluarga miskin seperti keluarga pengemis tunanetra ada beberapa batuan yang didapatkan seperti:

\section{Bantuan Pemerintah}

Beberapa program bantuan pendidikan yang diberikan pemerintah kepada rakyat miskin untuk dapat memiliki kesempatan yang sama menempuh pendidikan, yaitu: program wajib belajar sembilan tahun, BOS (Bantuan Operasional Sekolah) serta Bantuan Siswa Miskin (BSM). Seperti anak salah satu informan yang bernama ibu Sry (46 tahun) mendapat dana BOS di Sekolah Dasar 68 kota Bengkulu. Selain dari dana BOS ibu Sry juga mendapat bantuan dana PKH (Program Keluarga Harapan) yang diterimanya setiap tiga bulan sekali sebesar Rp.450.000,00 untuk membantu meringankan biaya pendidikan anaknya. Sedangkan anak ibu Mw dititipkan di panti asuhan oleh saudara dari pihak suaminya. Selanjutnya anak bapak Ad, bapak Dn dan ibu Az sudah tidak sekolah lagi, karena sudah berkeluarga. 


\section{Bantuan Non Pemerintah}

Bantuan yang diberikan oleh orang-orang sekitar merupakan hal yang dapat meringankan beban keluarga pengemis tunanetra dalam memenuhi kebutuhan pendidikan anaknya. Pernyataan salah satu informan penelitian tentang bantuan yang diberikan oleh orang-orang disekitar tempat tinggal mereka yaitu:

(...Sering juga kami dapat bantuan dari tetangga, seperti diberikan baju seragam sekolah bekas anak-anak tetangga tapi masih layak untuk dipakai, buku-buku pelajaran sekolah. Kami juga para pengemis sering diberikan bantuan oleh Rozi anaknya pak Ustad Zulkipli yang dermawan, bantuanya berupa uang, barang dan juga sembako...)

Dengan perbaikan ditingkat pendidikan maka kualitas sumber daya manusia yang dimiliki akan mengalami perubahan dan mengolah kemampuan yang dimiliki serta dapat membuat perubahan baik bagi diri sendiri maupun keluarga.

\section{Biaya Kebutuhan Kesehatan}

Untuk mengatasi berbagai permasalahan masyarakat miskin pemerintah menerapkan program yang dapat membantu masyarakat miskin dalam mengakses pelayanan kesehatan seperti program kartu indonesia sehat (KIS). Selain dari KIS pemerintah juga memberikan bantuan kesehatan kepada masyarakat miskin seperti pengemis tunanetra berupa Badan Penyelenggaraan Jaminan Sosial (BPJS). Keluarga ibu Sry dan bapak Bgs, keluarga ibu Az dan bapak Dn serta ibu Mw mendapat kartu BPJS ketika sakit tidak dipungut biaya untuk rumah sakit. Tapi menurut informan penelitian, para pengemis tunanetra ini lebih sering berobat secara tradisional, dikarenakan sakit yang diderita tidak begitu parah. Sakit-sakit ringan seperti flu, batuk, sakit perut dan juga sakit kepala. Para pengemis tunanetra lebih memilih beli obat diwarung-warung dan berobat tradisional seperti dipijat, karena sakit yang diderita tidak begitu parah dan juga obat diwarung lebih mudah didapatkan.

\section{Strategi Jaringan Pengaman}

Strategi jaringan pengaman bagi pengemis tunanetra dapat membantu menyelesaikan masalah keuangan ataupun masalah-masalah yang lainnya karena mereka merasa senasib sepenanggungan. Jaringan yang dibentuk oleh pengemis tunanetra seperti adanya kelompok Pertuni yaitu persatuan tunanetra Indonesia. Bahkan 
di kota Bengkulu pun kelompok Pertuni ini menjalin relasi yang positif antar sesama anggotanya, yang dapat memberikan manfaat bagi penyandang cacat tunanetra di kota Bengkulu. Berikut manfaat adanya jaringan atau kelompok pertuni kota Bengkulu yang dapat meringankan beban ekonomi bagi pengemis tunanetra kota Bengkulu:

A. Arisan

Dengan mengikuti arisan, keuangan dapat disalurkan dan mengatasi masalah perekonomian untuk keluarga miskin seperti keluarga pengemis tunanetra. Ibu Sry salah satu informan penelitian menyatakan bahwa anggota pertuni yang jumlahnya kurang lebih tiga puluh orang tersebut rutin mengadakan arisan bulanan. Dengan adanya arisan bulanan ini dapat membantu perekonomian keluarga pengemis tunanetra. Menurut ibu Sry sekarang ini, anggota Pertuni yang sama-sama penyandang cacat tunanetra yang aktif ikut arisan dan juga aktif dalam kegiatan pertuni hanya ada 12 orang. Arisan yang diikuti oleh ibu Sry ini perminggunya Rp.40.000,00. Arisan diambil giliran perminggunya sejumlahRp.480.000,00.

\section{B. Saling Memberikan Pinjaman Uang}

Dengan adanya jaringan maka pengemis tunanetra lebih mudah untuk dikumpulkan dan juga dapat membangun relasi yang baik dan positif baik antar sesama dan juga terhadap orang lain. Rasa senasib sepenanggungan membentuk solidaritas terhadap sesama tunanetra dan antar sesama pengemis tunanetra pun disaat bertemu mereka saling menyapa antara satu sama lain.

Pengalaman dari salah satu informan penelitian (ibu Mw, 40 tahun) yang menjadi tulang punggung keluarga, menghidupi anak-anaknya. Ibu Mw pernah meminjam uang kepada rekan-rekan sesama anggota pertuni sebesar Rp.200.000,00 untuk mengirim uang kepada anak-anaknya yang dipanti asuhan. Ibu Sry juga menyatakan bahwa setiap anggota pertuni wajib setoran perbulan sebesar Rp.10.000,00 sebagai kas untuk koperasi pertuni. Koperasi Pertuni ini juga dapat meminjamkan uang kepada setiap anggotanya. Namun karena uang yang disetorkan relatif kecil maka koperasi Pertuni Kota Bengkulu tidak begitu aktif dijalankan. Sistem peminjaman uangnya pun tidak menyulitkan para anggotanya, bagi yang meminjam uang maka dikembalikan sebesar uang yang dipinjamkan juga dan tanpa ada persyaratan. Yang menjadi bendahara Pertuni Kota Bengkulu adalah ibu Jana yang tinggal di Sawah Lebar dan juga seorang pengemis tunanetra. 


\section{Strategi Dalam Mengemis Waktu Yang Aman}

Waktu yang dipilih dan dianggap aman oleh pengemis tunanetra yaitu jam 9.00 pagi itu sudah berangkat dari rumah. Seperti Az (53 tahun) dan Dn (50 tahun) pengemis tunanetra ini lebih memilih jalan kaki untuk datang ke lampu merah Sukamerindu, sedangkan rumahnya berlokasi di sekitar pasar Minggu. Az dan Dn hanya mengemis di pasar-pasar dan di lampu merah saja. Dari mulai jam 9.00 WIB pagi sampai jam 17.00 WIB sore hari. Dn dan Az lebih memilih lokasi lampu Merah Sukamerindu karena lebih aman untuk mengemis.

\section{KESIMPULAN}

Berdasarkan hasil penelitian yang dilakukan maka diperoleh kesimpulan bahwa terdapat strategi yang dilakukan oleh pengemis tunanetra dalam bertahan hidup dan memenuhi kebutuhan sehari-hari yaitu dengan pengoptimalan potensi keluarga, meminimalisir biaya pengeluaran keluarga, serta dengan jaringan pengaman.

Dari ketiga strategi bertahan hidup yang dapat dilakukan oleh pengemis tunanetra untuk memenuhi kebutuhan hidup yang paling sering digunakan adalah strategi aktif dan strategi pasif, dikarenakan strategi aktif berupa pengoptimalan potensi anggota keluarga dapat membantu menambah penghasilan uang dikeluarga pengemis tunanetra begitupun strategi pasif dengan meminimalisir pengeluaran biaya kebutuhan pokok.

Selanjutnya alasan menjadi pengemis bagi pengemis tunanetra yaitu: pertama dikarenakan faktor latar belakang ekonomi yang rendah. Kedua, tidak adanya pekerjaaan yang dapat menampung pengemis tunanetra yang memiliki kondisi cacat pada penglihatannya. Ketiga, pendidikan yang rendah dan minimnya keahlian itu juga menjadi kendala untuk mendapatkan pekerjaan lain yang lebih layak. Dengan ketidakberdayaan secara ekonomi, secara fisik dan berpendidikan rendahlah yang menjadikan pengemis tunanetra sebagai pengemis untuk menghasilkan uang demi memenuhi kebutuhan sehari-hari.

Berdasarkan simpulan diatas, dapat diketahui bahwa mengemis yang dilakukan oleh pengemis tunanetra merupakan salah satu pilihan yang dapat dilakukan demi menyambung hidup, tidak adanya pekerjaan yang dapat menampung para pengemis tunanetra dengan kondisi cacat fisik serta minim keahlian. Maka dari itu, pihak 
pemerintah sudah seharusnya lebih memperhatikan kondisi masyarakat miskin yang memprihatinkan seperti pengemis tunanetra. Pengemis tunanetra tergolong dalam kelompok fakir miskin. Negara Indonesia mestinya menjamin masyarakat miskin seperti yang tertuang pada Undang-undang Dasar 1945 pada pasal 34 ayat 1 tentang fakir miskin dan anak terlantar dipelihara oleh negara serta pada Undang-undang Dasar 1945 diatur juga mengenai "keadilan sosial" yang artinya bahwa masyarakat miskin pun berhak untuk mendapatkan kehidupan yang lebihlayak seperti kehidupan masyarakat yang lainnya. Dan juga kepada masyarakat disarankan agar memberikan bantuan terhadap para pengemis tunanetra yang memang pantas dan layak untuk menerima bantuan. Serta untuk para pengemis tunanetra jangan hanya mengandalkan bantuan dari orang-orang saja, mulailah mencari alternatif lain untuk menghasilkan uang seperti berwirausaha atau berdagang.

\section{DAFTAR PUSTAKA}

Burhan, Bungin. 2001. Metode Penelitian Kualitatif. Jakarta: Raja Grafindo Persada.

Dimas, Dwi Irawan. 2013. Pengemis Undercover Rahasia Seputar Kehidupan Pengemis. Jakarta: Titik Media Publisher.

Hajar, G. Pramudyasmono dkk. 2011. "Perilaku Masyarakat Miskin di Kota Bengkulu dan Model Pengentasan Kemiskinan Berbasis Nilai Sosial Budaya Lokal”. 24(2): 151-152.

Khusnul, Ma'rufah. 2016. Kejadian Penyakit Ispa Pada Balita. Skripsi. Bengkulu: Universitas Bengkulu.

Ritzer, George. 1985. Sosiologi Ilmu Pengetahuan Berparadigma Ganda. Jakarta: Rajawali.

Silalahi, Ulber. 2009. Metode Penelitian Sosial. Bandung: Refika Aditama.

Sugiyono. 2015. Memahami Penelitian Kualitatif. Bandung: Alfabeta.

Suharto, Edi. 2003. Coping Strategies dan Keberfungsian Sosial: Mengembangkan Pendekatan Pekerjaan Sosial Dalam Mengkaji dan Menangani Kemiskinan. Diakses 22 Januari, 2018 (http://www.policy.hu/suharto/). 
Sukandarrumidi. 2012. Metodologi Penelitian Petunjuk Praktis Peneliti Pemula. Yogyakarta: Gadjah Mada University Press.

Sukandarrumidi. 1980. Lembaran Negara Republik Indonesia. Sekretariat Negera Republik Indonesia 